\title{
ELŐSZÓ A TUDOMÁNYMETRIAI TEMATIKUS SZÁMHOZ
}

A tudománymetria a kutatók, a tudományos intézmények és a tudományos kiadványok, mint folyóiratok és konferenciakötetek stb. teljesítményének mérése és annak módszertana.

A Vezetéstudomány ez évi második tematikus száma a tudománymetria gazdaságtudományi oktatókra-kutatókra való alkalmazásának bemutatását tűzi zászlajára. A tematikus szám öt tanulmányt tartalmaz a gazdaságtudományok különböző területeiről, de kiemelten a gazdálkodástudományból.

Dobos Imre dolgozata a magyar gazdaságtudományi kutatók teljesítménymutatóit vizsgálja a gazdaságtudományban, tehát a közgazdaság- és gazdálkodástudomány területén egyaránt. A vizsgálathoz az Elsevier kiadóhoz kapcsolódó Scopus és SciVal adatbázisokból gyüjtött adatokat használ. Az elemzésnek kettős célja volt. Egyrészt a két adatbázisból kinyert mutatók közötti lineáris kapcsolatok feltérképezése, és ezzel a mutatók számának csökkentése. Másrészt a vizsgálathoz kiválasztott kutatók közötti csoportok feltérképezése, vagyis publikációs mintázatok bemutatása. Az eredmények azt mutatják, hogy a magyar gazdasági kutatók elég hasonló publikációs stratégiát folytatnak. Kiemelkedő publikációs mutatókat csak a vizsgálatba bevont kutatók tizede mutat fel.

Sasvári Péter László, Bakacsi Gyula és Urbanovics Anna a társadalomtudományi akadémiai bizottságok MTA doktori eljárásainak habitusvizsgálatához kialakított folyóiratlistákat állítják a vizsgálat középpontjába. Ezek a listák a tudományterület hazai oktatói-kutatói teljesítményértékelésében meghatározó szerepet töltenek be. A nemzetközi felsőoktatási piac felé nyitni szándékozó intézmények hazai és nemzetközi rangsorokban elfoglalt helyét ugyanakkor a nemzetközi indexált adatbázisok, mint a Scopus és a Web of Science folyóiratlistái alapján mért kumulált publikációs teljesítményekre alapozva számítják. A tanulmányban a szerzők az MTMT2 adatbázisa alapján azt tárják fel, hogy mekkora különbségek adódnak az egyéni publikációs és idézettségi teljesítmények megítélésében e kétféle lista alapján való értékelésében. Az eltérés bemutatásán túl a cikk elemzi a különbségek valószínüsíthető követelményeit - mind egyéni, mind intézményi szinten. Végül lehetséges megoldási alternatívákat is megfogalmaz a kialakult helyzet feloldására.

Krajcsák Zoltán és Szabó István tanulmányukban a publikációs kiválóság tudományos közösségben folyó értelmezési vitájában a gazdálkodástudományok vonatkozásában állást foglalnak a nemzetközi, minősített folyóiratcikkek kiemelt szerepe mellett. A szakterület fejlődéséhez, a nemzetközi kutatásokban való sikeres közremüködéshez, eredményeink láthatóságának növeléséhez nélkülözhetetlen a nemzetközi folyóiratcikk-publikációk ösztönzése. Ezen túlmenően szakpolitikai igény, hogy elsősorban azok kapjanak finanszírozást, akik várhatóan előmozdítják a tudományt világszinten is. Az ösztönzés során figyelembe kell venni, hogy a teljesítményértékelési rendszerek sajátosságai önmagukban is mintául szolgálnak az egyéni publikációs stratégiák kialakítása során. Amíg a habilitációs, egyetemi tanári, MTA doktori címek megszerzésének feltételeként elöírt, nemzetközi folyóiratcikkekre vonatkozó elvárások inkább csak jelképesen írják elő ezek teljesítését, addig egyre nagyobb a veszélye annak, hogy a hazai kutatók teljesítménye mindinkább elmarad a közép-európai átlagtól. A dolgozatban a szerzők bemutatják ennek egyik lehetséges ösztönzőjének, a tudomanymetria.com projektnek a szerepét a tudományterületi jellegzetességeket és a kutatói életkort is figyelembe vevő publikációs kiválóság értékelésében és ismertetik a közeljövőben történő, a szakterületet érintő fontosabb változásait is.

Mihály Nikolett, Vinogradov Szergej és Suhajda Csilla Judit munkájukban az MTMT adataira épülő empirikus kutatást mutatnak be, amely a hazai gazdaságtudományi képzések oktatói publikációs és idézettségi teljesítményének mérésére használható mutatók közötti összefüggések feltárására irányult. Vizsgálataikat 17 magyar felsőoktatási intézmény docens munkakörben foglalkoztatott 681 oktatójának főbb tudománymetriai adataira alapozták. A tudományos publikációs teljesítmény mérésére használható mutatók között az MTA IX. Osztálya által A, illetve B kategóriákba sorolt hazai kiadású, valamint a Q1, illetve Q2 besorolású folyóiratokban megjelent cikkek számát, valamint a Hirsch-index értékét vizsgálták. A vizsgálat eredményei jelentős publikációs teljesítmény-színvonalbeli eltérést mutatnak az intézmények között. A vizsgált intézmények esetében, a magas besorolású cikkek számával mért publikációs teljesítmény és a Hirsch-index értéke között lineáris kapcsolat állapítható meg. Az egy oktatóra jutó hallgatók száma és a tudománymetriai mutatók közötti összefüggések vizsgálata ellenben nem hozott egyértelmủ kapcsolatot. Igazolást nyert ugyanis, hogy míg a tudományos visszhangot mérö Hirsch-index értéke jelentősen alacsonyabb az egy oktatóra vetítve legnagyobb hallgatói létszámmal rendelkező intézmények esetében, addig a magas besorolású folyóiratokban megjelent cikkek száma hallgatói létszám alapján képezhető középső csoportban magasabb a másik két szélső csoporthoz képest. Eredményük rámutat arra, hogy az MTA IX. Osztálya által A, illetve B kategóriásként elismert folyóiratot gondozó felsőoktatási intézmények docensei magasabb tudományos publikációs teljesítménnyel rendelkeznek a magas besorolású hazai folyóirattal nem rendelkező intézmények oktatóihoz képest. 
Wimmer Ágnes, Takácsné György Katalin, Koloszár László és Mitev Ariel dolgozatukban az Országos Tudományos Diákköri Konferenciák (OTDK) adatait dolgozták fel. Az OTDK-kon több ezer hallgató vesz részt 16, tudományterületenként szervezett szekcióban, tartalmilag és módszertanilag igen sokszínủ pályamunkák bemutatásával. A kétévente megrendezett esemény versenyjelleggel is bír, szakmai tagozatonként csak egyetlen dolgozat érhet el első helyezést, így jelentős felelősség hárul az értékelési folyamat résztvevőire. A TDK egyben a felsőoktatási tehetséggondozás kiemelt, hét évtizedes hagyományokkal rendelkező fóruma, ahol fiatal kutatók próbálják ki magukat: többségük számára az OTDK az első alkalom, amikor külső szakmai visszajelzést kaphatnak munkájukra, ennek milyensége befolyással lehet pályájukra, a kutatáshoz való viszonyukra. Az elemzésben az értékelés szerepét és kihívásait vizsgálják a szerzők az OTDK jelenleg legnagyobb, Közgazdaságtudományi Szekciójának tapasztalatai alapján, az írásbeli bírálatokra fókuszálva. Kiemelik a bírálati folyamat jellemzőit más felsőoktatási, illetve kutatási/publikációs értékelési helyzetekhez képest, megfogalmazzák az értékeléssel kapcsolatos elvárásokat, rámutatunk a föbb kihívásokra és a folyamat fejlesztésének irányaira. A tanulságok a tehetséggondozáson túlmutatóan a tudományos, oktatói-kutatói pályán előforduló más értékelési szituációk jobbítását is segíthetik.

A tematikus szám cikkei alapján megfogalmazható egy olyan összefoglaló következtetés, hogy a tudományos teljesítmények mérésén alapuló nagy adatbázisokon pontosabb és finomabb elemzések végezhetők a megbízhatóbb, a kitűzött célok elérését jobban szolgáló teljesítményértékelés érdekében, egyben ezek lehetőséget teremtenek a tudatosabb publikációs stratégiák megfogalmazására is mind egyéni, mind intézményi szinten.

A következtetések innen többfelé ágaznak:

- a tudománypolitika szintjén fontos lenne az egységes és következetes - a tudománymetriai mutatókkal jó mérhető és dokumentálható - intézményi oktatói-kutatói és teljesítményelvárások megfogalmazása és az ezek dokumentálására alkalmas nyilvános és közhiteles platformok fejlesztése. Az intézményi finanszírozás szempontjából lényeges pályázatok elvárásai képezzenek koherens egységet az intézményfejlesztési pályák kritériumaival.

- az intézményi szint a maga stratégiája tükrében tudatosan alakítsa saját tudományos és publikációs politikáját, ez képeződjön le az egyéni teljesítménymérési és -értékelési rendszerekben visszatükröződő elvárásokra. Az ez alapján mért teljesítmény képezze az alapját a karriermenedzsment-rendszereknek, ez alapján fogalmazódjanak meg a karrierpályák és az ezeket támogató rendszerek. Az intézményi erőforrás-elosztó és ösztönző rendszerek következetesen támogassák ezeket!

- az egyéni szinten a tudatos publikációs stratégia és az ehhez nélkülözhetetlen habitus kialakítása alapozza meg a karrierpályákon való elörehaladást.

- a tudományos és kutató pályákra történő toborzásban és kiválasztásban is (TDK, diáktudományosság, Doktori Iskolák Ph.D. programjai) jelenjen meg ez az értékelési szemléletmód és kezdődjön meg e habitus kialakítása.

\section{Szerzők/Authors:}

Bakacsi Gyulaa (bakacsi.gyula@uni-bge.hu) egyetemi tanár; Dobos Imreb (dobos.imre@gtk.bme.hu) egyetemi tanár; Sasvári Péterc (Sasvari.Peter@uni-nke.hu) egyetemi docens

\footnotetext{
a Budapesti Gazdasági Egyetem (Budapest Business School), Magyarország (Hungary); 'budapesti Műszaki és Gazdaságtudományi Egyetem (Budapest
} University of Technology and Economics), Magyarország (Hungary); ‘Nemzeti Közszolgálati Egyetem (University of Public Service), Magyarország (Hungary) 